\title{
山崎静太郎設計の入れ子式能楽堂から見た能楽堂改良論の導入について A STUDY ON THE INTRODUCTION OF IMPROVEMENT DISCUSSIONS FROM IREKO STYLE NOH THEATER ON YAMAZAKI SEITARO'S DESIGN WORKS
}

\author{
奥 冨 利 幸* \\ Toshiyuki OKUTOMI
}

\begin{abstract}
This paper, I analyze how the Improvement Discussions at Meiji era influence the Ireko style Noh Theater. For the case study, I pick up Architecture Yamazaki Seitaro who is well known for an authority of Noh. He designed Hosokawa and Umewaka Noh Theater. From these two examples, using Yamazaki's design summary and the first discovered plan of Hosokawa Noh Theater, I inspect how Improvement Discussions on Noh Theater influenced the formation of Ireko style Noh Theater.
\end{abstract}

Keywords: Nohgaku, Noh theater, Yamazaki Seitaro, Ireko style Noh Theater 能楽，能楽堂，山崎静太郎，入れ子式能楽堂

\section{1. はじめに}

1912（明治 45）年の帝国劇場への能楽の出演依頼の可否を巡る議 論である「帝劇出演問題」に端を発した「能楽改良」が、大正期に 入って、池内信嘉などの能楽界の論客により議論注1) される中で、 建築的観点での議論として注目されるのが、雑誌『能楽』の座談会 として、1910（明治 43）年の第 8 巻の第 1 号から 12 号までに連載 された「能舞台研究会」で、山崎静太郎、後藤慶二、上野肇らが議 論に参加したが、この研究会の主旨は、能舞台の様式の原点を探る ものであった。また、この研究会は、次の「能楽堂改良会」への布 石でもあった。一方、「能楽堂改良会」は雑誌『能楽』に、1911（明 治 44）年の第 9 巻第 1 号から 11 号まで連載された座談会で、当時 の能楽堂の問題点と改良論が論じられた。この座談会の参加者は、 山崎静太郎、後藤慶二、上野肇、咲寿栄一などで、中心的な役割を 演じたのは、山崎静太郎と後藤慶二であった。この会では、「舞台見 所の関係改良案」、「楽屋の設備」「食堂案」など七つのテーマを挙 げて、改良案を提案する形式で討論が行なわれた。そして、この座 談会の中心メンバーで、その後に実際に能楽堂の設計を手がけるこ とになるのが、山崎静太郎である。

本論では、山崎静太郎が大正期に設計した入れ子式能楽堂である 細川家能楽堂と梅若家能楽堂を取り上げて、この二つの能楽堂が実 際に能楽改良の議論からどのような影響を受けて設計されたのかを 分析してみたい。

\section{2. 細川家能楽堂}

細川家能楽堂は、1918（大正 7）年に東京麹町区富士見町 5 丁目 7 番地の細川侯爵富士見別邸内に竣工した能楽堂である。

山崎静太郎は細川家能楽堂について、「新能楽堂三つ」注2) と「細 川侯爵家新築能楽堂の概要（上）・(下）」注3）（表 1）で、能楽堂の 設計主旨について詳しく論じており、ここから能楽堂の設計内容を 抽出し、能楽堂改良論との比較検証をしてみたい。

まず、「新能楽堂三つ」には平面図が掲載されておらず、山崎はそ の理由として「能舞台其者は大方きまり切つていますし、周囲の観 覧席や諸室の配置も大体に同じやう」と述べている。しかし、能楽 改良論の影響を検証する上で、平面図は極めて重要な資料となるた め、筆者は細川家の関係史料を保管している永青文庫を訪れ、当時 の関係史料注4）を閲覧して、「細川家能楽堂配置図注5)」(図 3) 及び 「細川家能楽堂平面図注 6)」(図 4)を確認することができた。本論で はこの図面も資料に使って検証を進めたい。

資料によれば、敷地は約 2,111 坪で、能楽堂の他に借家が 17 軒建 てられていた。この借家については、山崎は「地所は細川家の所有 で、ここには同家の家作許りがある、家職の舞ひ手で鋝々の一人な る笠五朗氏や、喜多流の沼田勇魚等も此の廓内に住んで居られる。」 注7) と述べており、借家の一部には、細川家お抱えの能楽師が住ん でいたことがわかる。また、能楽堂は、敷地の南東側角地に建てら れており、角のところは池を配した庭園のように描かれている。庭

\footnotetext{
* 小山工業高等専門学校 准教授・博士 (工学)
}

Assoc. Prof., Oyama National College of Technology, Dr. Eng. 
園はちょうど能楽堂の地裏側の畳廊から見るようになっており、能 楽堂に附属した茶室は、池の北側に配置されている。この茶室のあ る建物について山崎は、「もとは御殿の一つで、先代侯爵の薨去後他 一貸与せられてるたものである。此の御殿の広い泉庭向きの座敷は 下が日本間上は洋館となつてみて、それに続いて平屋建てがあつた のを、その平屋部分丈け取り毁ち、他に土蔵や物置などのあつたの も取り払つて能楽堂とし、残存の二階建てが能楽堂に接続すること となつてみる。」注8) と述べており、能楽堂に付属する二階建ての部 分は、元の細川護成邸の一部であり、御殿に続く平屋、土蔵、物置 を取り壊して、能楽堂を建設したことがわかる。能楽堂へのアプロ 一チは、南西側の一番広い接道から借家の間の通路を入った場所に 正門があった。

次に山崎の設計主旨から能楽堂各部の概要を明らかにすると共に 能楽堂改良論からの影響について検証してみたい。

\section{(1) 玄関}

正門の正面を進むと能楽堂の南西角部に到達し、西面に一般入り 口、南面に主立関を置いて玄関を区分しており、これは貴賓訪問に 備えてのことであろう。また、この玄関について山崎は、「正門を入 つて主玄関は右向きに付いてるるから、車類は略真直に輓込んで車 寄へ付ければよい事になつている。」として、主玄関では、車での来 賓を前提に考えられていたことがわかる。なお、能楽堂改良会では、

「下足受渡改良案」として議論され、いかに多数の観客が迅速に入 場と退場ができるのかということを主旨に、玄関の形状案を提示し ていた。しかし、細川家能楽堂では、貴賓用の主立関と一般入り口 の二つの玄関を設けているが、一般入り口の形状は土間の一方に式 台を設けたもので、能楽堂改良の提示案は採用されていない注9)。

\section{(2) 見所空間}

細川家能楽堂の見所天井は化粧屋根裏天井となっている。(図 1) この天井について山崎は、「屋根の勾配が早や過ぎはしないかとい ふ故後藤君の当時の批評は私の首肯した処であります。然しこれは 上屋の重荷を受ける為に力の點から止むを得なかったのです。舞台 の天井が化粧屋根裏ですから、小屋裏に構造上必要な空間を有せし める為めには、これ丈の勾配がどうしても入用でした。と述べて、 上屋の切妻屋根を構造上安定させるために、急勾配としたことがわ かる。また、「上屋の構造主材は合掌丈けで、陸梁を使っていないの ですから、舞台の屋根上で束を以て受けるより仕方がなかったので す。尤も舞台前方、即ち正面席の頭上には、仕方なしにタイバアを 取り付けました。として、この小屋組構造は、合掌材で保持してい ることを述べ、また、そのために、屋根の荷重を能舞台の棟の上部 に束を立て支持していることを説明している。

入れ子式能楽堂の見所の小屋組をこのとき始めて手がけた山崎 にとって、見所の大空間を確保は大きな問題点となっていたことが わかる。そして、上屋屋根と能舞台をいずれも切妻屋根としたこと で、上屋の小屋組を組むことができずに、その解決策として、合掌 材上部をつなぐタイバーと能舞台屋根上部の束に解決を求めるほか になかった。つまり、入れ子式とすれば、鞘堂である能楽堂本体は、 大きなボリュームを持つことになり、従来の和小屋では、処理でき なくなる。この件について、能楽堂改良会注１０）では、「西洋風の鉄
骨構造」を解決方法として提案し、見所も一緒に西洋風にしても、 能舞台との対比において面白みがあるとしていた。しかし、鉄骨の トラスとしても、その下端は能舞台の棟よりも高くしなければなら ず、相当に大きなボリュームの鞘堂となる。理由は定かでないが、 ここでは採用されなかった。

また、山崎は能舞台の屋根の見え方で、興味深い見解を述べてい る。つまり、「これまでのどの能楽堂も舞台の全容を見得ないのが一 大欠点でそれを避けたのは浅野侯爵家滝の川別邸の舞台一つである。 宝生会のは余程天井を高くしたが、夫れでも陸（水平）天井である 為め舞台の屋根の半ばは天井に隠れ、恰も天蓋が垂つたやうな形に なつてみる。それで今度は大体浅野家のに倣ひ、舞台上へ勾配屋根 の大屋根を設け、合掌も母屋も杉の皮付磨き丸太とし、垂木は吹き 寄せとして裏板を見せ、外は土居莫スレート莫とした。」また、「浅 野家のは二つ以上の小室で構造してみたが、此の方は全部一つの小 屋で覆ひ、又釣り鉄材を見せない事にした点は更に一歩を進めたも のと信じてわる。その代り力学上構造に骨の折れた事は一通りでは なかった。と述べており、この入れ子式能楽堂を造る上で参考にし たのが、浅野侯爵家滝野川別邸の能舞台であったことが伺える。浅 野侯爵家滝野川別邸の能舞台は、囲繞式に分類されるものであるが、 能舞台と見所の間の白州が大きく取られて、その上には片流れの屋 根が掛かり、側面に大きな開口部が明けられている。そのため、見 所から能舞台の屋根が見えたのかも知れない注 11 1)。さらに、宝生会 能楽堂注 12 2) の陸天井で能舞台の屋根の隠れることの欠点を考慮し て、勾配屋根の大屋根の形状を決定したということである。この件 について能楽堂改良会で後藤慶二が「能舞台屋根が見所から見えな いことは、能舞台の芸術的進化の形式を無視したこと」と述べてお り、見所から能舞台の屋根を見せることの重要性を強調していた。 したがって、山崎が見所からの能舞台の屋根の見え方に考慮したこ とは、能楽堂改良論でのこうした議論を反映させたことになろう。

\section{(3) 見所席割}

細川家能楽堂の平面図（図 4）を見ると、能舞台を中心として、 見所は桝席が正面と脇正面、地裏側にも配置され、各桝席の後には 通路が取られている。これは、能楽堂改良会での「通路を増やし他 の席を踏まずにどの席にも行けるようにする。」注１3）という議論に 沿う平面構成となっている。また、枰席について、山崎は次のよう に説明している。「正面に三段合計四十七席、脇正面に四段合計三十 席、地裏に一段合計八席、総計八十五席。一席の大きさは巾三尺に 長サ四尺五寸、然し各席悉くその後部に一尺五寸の通路を取り、こ れが、座席と水平になってみるので、実際は席中から後方へ食み出 ても不便を感じないから、一席に五人詰としてもさして苦しくはな い筈である。席割観覧場は、後方より前方へ六寸下り篗壇とし、席 の直後は前記の如く席面と同高の通路 (一尺五寸) を付けてるる外、 横に五席乃至六席毎に縦に通ずる路（一尺五寸）をも付けることと した。この中で、栘席の大きさについては、「巾三尺に長业四尺五 寸」とあり、二人が並んで座るほどの巾となっているが、能楽堂改 良会では、「前列三人、後列三人都合六人がゆっくり並べる位」と発 言されていたので、これほどの巾は実現できなかったことになる。 その理由としては、桝席が幅広になれば奥行き狭まり、観覽や出入 
の上では都合がよいが、通路の本数が増える分で栘席の数が減り、 定員が少なくなることが考えられる。一方、席割り観覽場は後方よ り前方へ六寸さがりの雛壇となっており、これは、「雛壇は後方に行 くほど高くする」とした能楽改良会の意見が反映されている。

また、この能楽堂の見所の特徵として、貴賓席にあたる栈敷席の 広さが大きいことが挙げられるが、この点について山崎は次のよう に説明している「御覧座敷があつてこれは畳敷、奥より数えて十畳、 八畳、八畳の三室、此の中十畳間は床棚付きで三方が建具、次きの 八畳が舞台に対して真正面で四方建具、次きの八䪶も同様である。 演能の際は、正面の建具を取払つて膝隠しを立てることとなつてみ るが、演能以外の一寸した集会は三室を併せて二間に六間半の大座 敷となし得る訳である。(略) 而して御覧座敷前では通路を特に三尺 としたのである。」この中で、まず、能楽堂改良会での議論と一致し ていない部分は、御覧座敷の前を通路にしている点である。つまり、 能楽堂改良会では、「御間の前に多少の余地を置き、その又前に通路 がある事とすれば、通路が直接御間の前に連らなつてみないから、 なほ一層よくなるであらうと思ひます。」と山崎自身が発言していた が、席数の関係であろうか実施されていない。また、全部合わせる と 26 畳にもなる広い栈敷席が、演能以外の使用も考えられていたこ とがわかった。普段は座敷として使い、演能のときは建具を取払っ て、膝隠しを立てて使うということである。しかし、この座敷の造 り方の特徵として、能舞台の正面が二の間の正面にあることである。 伝統的規範である最も格式の高い部屋の正面に据えるという原則が 守られていない。当時、最も充実した能楽堂で、この細川能楽堂の 御覧座敷でも模範とされた九段能楽堂（旧能楽社）でも、御覧所は 能舞台の正面に配置されていた。しかし、御覧座敷が能舞台正面に 合わせられなかった点は、この能楽堂が行幸啓を前提として考えて いなかった理由が考えられる。なぜなら、行幸啓では能舞台の正面 に御覧所を配置することが規定されていたからである。この点につ いては、大正時代に入り、明治期のように頻繁に華族邸宅への行幸 啓とそれに伴う能楽御覽が行われなくなったことが背景として、考 えられよう。

\section{（4）舞台採光}

採光に関して山崎は次の通り説明している。「上屋の妻から高く 明かりを取る事にした為め、舞台は切妻にしました。つまり、この 能楽堂では、能舞台と鞘堂である能楽堂本体のいずれも切妻屋根で あるが、鞘堂の妻部から光を導き、その光を舞台奥まで届かせたこ とになる。これは、舞台の正面からの採光を考える上で最も合理的 な方法であった。能楽堂改良会では、第三回目に能舞台の採光案注 14) が論じられたが、ここでは、照明器具の選択について論じられ たのであり、昼間の採光の導入に関しては論じられていない。能舞 台を見所から写した写真（図 1) では、能舞台の屋根妻側が採光に より明るく照らされているのが分かり、また、能舞台の内部を写し た写真（図 2) でも鏡板の部分まで光が差し込んでおり、採光が適 切に採られているように見える注 1 5)。能楽堂改良会では、入れ子式 能楽堂が前提に議論されている傾向があり、採光に関しては積極的 な議論がなされなかった。

(5) 楽屋
楽屋については、「楽屋は言うまでもなく舞台および橋掛り裏全 部」と述べられているように、能舞台と橋掛りの裏側から溜りにか けて矩折りに配置されており、能楽堂改良会の第四回目の楽屋の設 備注 16 ）で、シテとツレ、後見方の部屋は 14 畳の部屋を一部屋、鏡 の間に一番近い方へとる。地謡方は 40～50 畳を一部屋、流派ごとは 衝立で分ける程度とし、切戸口へ最も近い方一配置する。ワキは二 部屋で各 20 畳、狂言方も二部屋で各 20 畳、稚し方は一部屋で 20 畳、大鼓方に 4 畳半、他にも皮焙室、物置、大きな便所、談話室兼 用飲食室 20 畳、楽屋の頭取世話人用の部屋 6 畳、後見方の溜り場 6 畳、結局合計 120 １30 坪位の楽屋が想定されていたが、これは理想 論であり、細川家能楽堂の規模からはかけ離れた大きさであった。 あえて類似点を挙げるなら、鏡の間から切り戸口にかけて楽屋を設 け、その脇に楽屋便所がある点で、楽屋の配置として能楽堂改良論 の議論を踏襲し、楽屋が仕切らない点などで、柔軟な楽屋の使い方 に配慮したと言えよう。

\section{（6）能舞台}

能舞台の切妻屋根形式選択の理由について、山崎は次のように論 じている。「足利時代は切妻で、桃山時代から入母屋が出来るやうに なり、徳川時代では主な能舞台は入母屋が規式になっていました。 然し略式のものには切妻もありました。此の舞台は金春流の藝に調 和させる為めに古風を取るのがいいと思ったので、一つは候爵家の 娛楽場として略式がよかろうと考えたからです。」つまり、能舞台に ついては、能舞台研究会の第 10 回目注 17) の議論で、桃山時代以降 の能舞台の屋根形状を議論しているが、西本願寺北能舞台を事例と して、創始が切妻屋根であると結論付けている。この屋根形状の古 式と細川家のお抱え能楽師の流派であった金春流を結び付けて議論 が展開されていたのである。

さらに、能舞台の意匠についても伝統様式との関連で説明がなさ れている。つまり、「従って蟇股も本式の二つづつとはせず各面一つ づつにしました。デテイルは足利時代のよりももつと古いものに似 たのが多いのです。鎌倉時代のデテイルが最も多く入って居る事に なってみましやう。これは何にも鎌倉時代を専ら尚んだ次第ではな く、形を作って行く間に自分の好みが自づから出て夫れになってし まつた丈けのものです。東大寺の鐘楼が或るヒントを与へている事 も否まれません。」や、「正面の桁の鼻に彫の平金物（実は木彫です がブロンズ仕上げにしています）を打ちました。これは技巧的には 効を奏したやうです。寫眞ではよく分かりませんが…このヒントは 鳳凰堂から受けてわるわけです。」な゙、デザインのモチーフが能舞 台の範疇に留まらず、また、時代的にも東大寺鐘楼や鳳凰堂を引用 するなど一貫性がない。また、「組み物の斗肘木は、すべて古式の和 様を取って背高面取り、斗と斗との開きも多くしたかわりに四方蛙 股は各一個づつ。これも形を古風にとり、中へ細川家の九曜紋を抜 いて入れた。として、伝統様式を重視しながらも自らの好みを取り 入れており、その意匠における様式の自由度が大きかった点が注目 される。そして、この点について山崎は、「板蟇股が大変古い様式で、 人によれば不都合だといふ評も出されるか知れませんが、私は時代 を離れて、唯形の上から、これで調和は得てるると信じて用みまし 


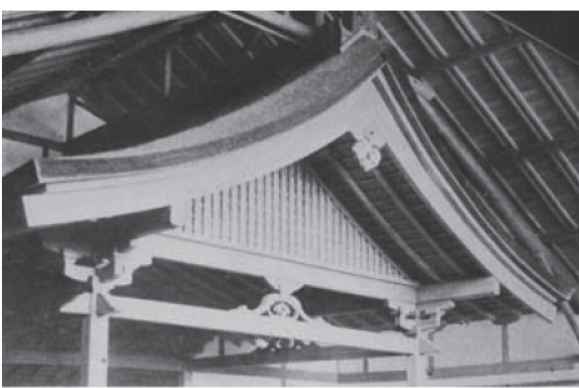

図 1 細川家能楽堂見所天井 (『建築雑誌』34 巻 398 号, 1920 年 1 月)

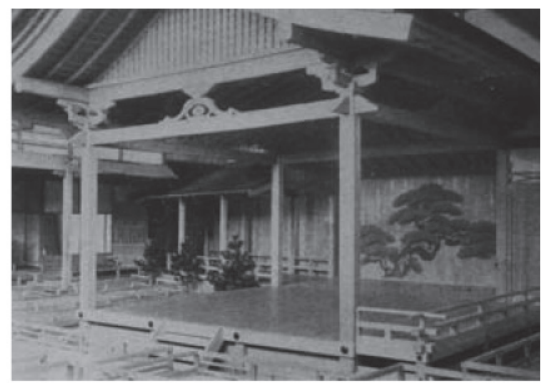

図 2 細川家能楽堂能舞台 (『建築雑誌』34 巻 398 号, 1920 年 1 月

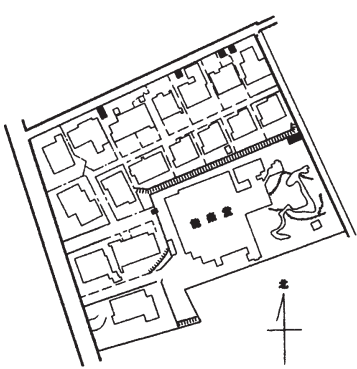

図 3 細川家能楽堂配置図(「貸家家屋台帳」 1931 年 11 月永青文庫所蔵より筆者作成
表 1 細川家能楽堂概要リス卜 (『能楽』 15 巻 $10 ・ 12$ 号, 1918 年)

\begin{tabular}{|c|c|}
\hline & 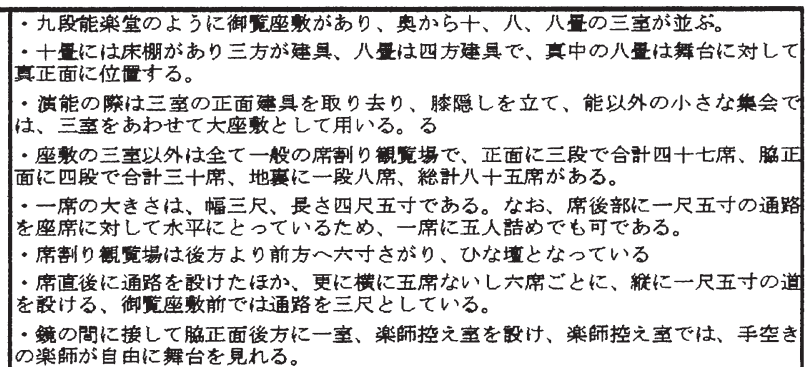 \\
\hline & 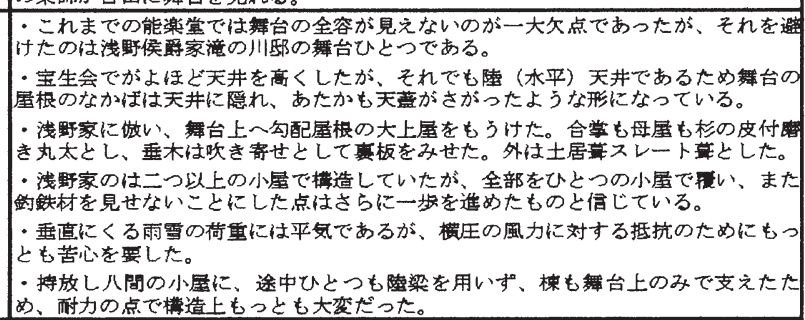 \\
\hline & 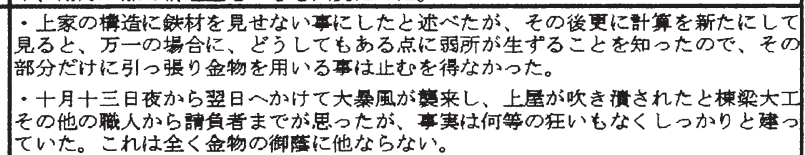 \\
\hline & 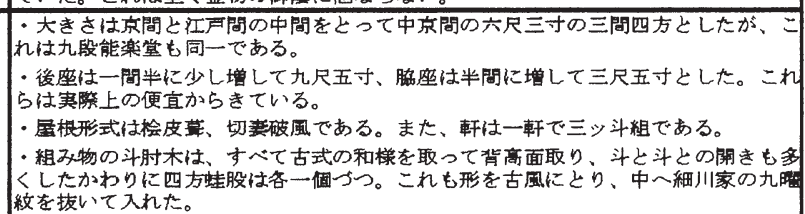 \\
\hline & 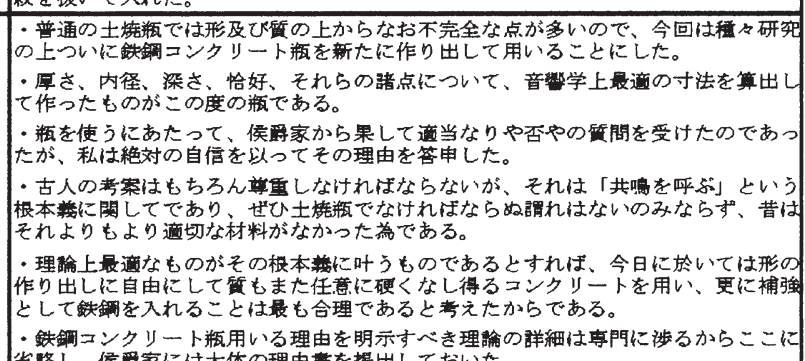 \\
\hline & 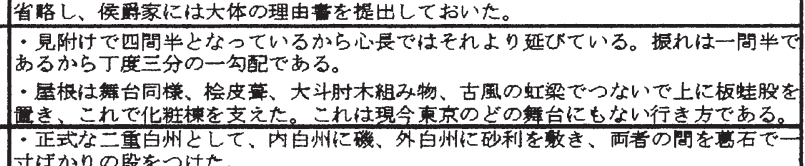 \\
\hline & 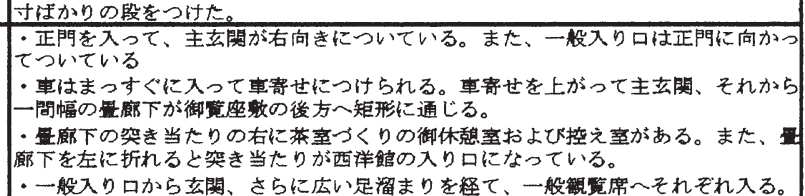 \\
\hline & 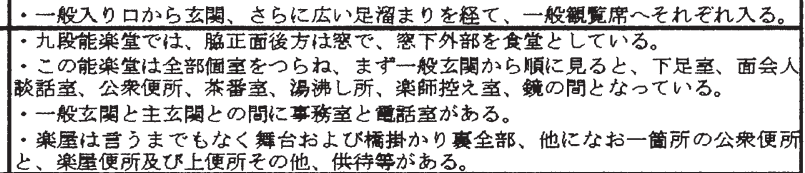 \\
\hline
\end{tabular}

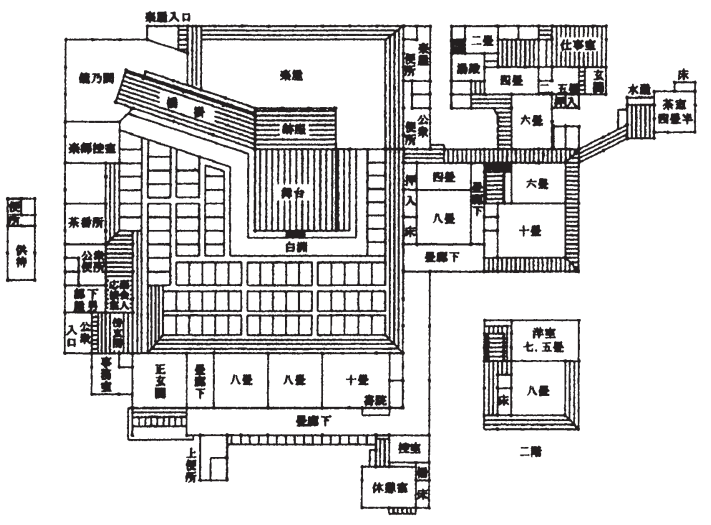

図 4 細川家能楽堂平面図 (「貸家家屋台帳」1931 年 11 月永青文庫所蔵よ り筆者作成)

た。尤も好む処に偏してはみましやうが。」という発言からも伺うこ とができる。その一方で、能舞台の平面形状については、「大きさは 京間と江戸間の中間をとって中京間の六尺三寸の三間四方としたが、 これは九段能楽堂も同一である。」として、伝統を重視して、当時の 最も中心的な能楽堂であった九段能楽堂に合わせて設計されたこと がわかった。

\section{3. 梅若家能楽堂}

梅若家能楽堂は、1919（大正 8）年に竣工した能楽堂で、浅草区 南元町 38 番地の厩橋の河畔に建設された。施主は、梅若実の子息の 万三郎と六郎である。この能楽堂の改築祝能の記事が『時事新報』 注18)に掲載されている。この能楽堂は、『時事新報』にも改築され たと報じられていたように、父の梅若実が青山下野守邸から譲り受 けた能舞台を移築して使うことで計画が進められた。また、敷地内 には、万三郎と六郎の住宅も造られたが、二人が同じ敷地に住み始 めたのは、新しい能楽堂ができる以前からのことで、このことは、 六郎の語りを白州正子が書き残している注 19$)$ 。つまり、兄の万三郎 を浅草三筋町から呼んだのが、三十の時というから、1908 年（明治 41 年）頃から兄弟で、同じ敷地内に住み始めたということになる。 したがって、この能楽堂も住まい兼用であったことがわかる。

続いて、能楽堂各部の概要と能楽堂改良論からの影響について検 証してみたい。

(1) 玄関

玄関については、あまり触れられておらず、次のような簡単な説 明がある。「正面席と脇正面席との入り隅の所です。襖の外は一間幅 
の廊下になつてみます。玄関はその廊下に接してみるのです。デテ イルに就て二二説明してもいいことがありますけれども面倒ですか ら省いて置きます。」つまり、見所の正面と脇正面の入る隅部に見所 への主要な出入り口があったことになる。また、梅若家能楽堂の平 面図（図 7）をみると、能楽堂改良会の「下足受渡改良案」で提示 された下足受渡改良案とは異なるものの、土間を三方から囲み昇降 ができるように見えるので、玄関口を分割して迅速な出入を図ると いう改良会での主旨は踏襲されたと考えて良いだろう。

\section{(2) 見所空間}

梅若能楽堂は、大きな切妻屋根が架けられ、その中に能舞台が収 められている。また、平面構成では、能舞台の正面と脇正面に枡席 が設けられ、二階席も設けられている。この設計について、山崎は 二階栈敷を設けたことが、天井が高くした理由であったと述べてい る。そして、この大きな見所空間を包む外観の立面図（図 8）を見 ると、見所を内包寸る切妻の大屋根とその周囲の諸室の屋根が回り を取り囲んでおり、能楽堂改良会で山崎が論じていた「外から見る と大きな建物があって、それの腰に三方裳腰が付いてみるといふ形 ですな」という表現に合致した空間構成になっていたことがわかる。 また、梁間の広い空間を確保するために、小屋組構造の詳細は不明 であるが「木鐵交りのトラス」としている。また、能楽堂改良会で は、見所の大空間の構造に鉄骨を用いた場合には、それを西洋式意 匠にしても面白いという意見も出されており注 20 )、見所の大空間で は、構造の必要性により、日本の伝統様式には拘らない姿勢が見受 けられたが、この能楽堂では、伝統意匠に則った姿勢が見られる。

\section{(3) 見所席割}

見所は枡席としているが、「観覧席は正面から後方へ(脇正面から も同じく)、少しづつ上げて行きました。と山崎が説明しているよ うに、細川家能楽堂と同様に雛壇としていたことがわかる。また、 能楽堂改良会注 2 1) で山崎の提案した「通路を増加し、どの席にも他 の席を踏まないで行ける様にしたい」という意見に対し、上野が出 した「前列の席はその前の廊下から、後列の席は後の廊下から這入 るといふことにすればよい。という意見がここでは採用されている。

\section{（4）舞台採光}

照明器具について山崎は、「天井の面積が大きい為に、その空漠と して締まりのないのを幾分補う目的で、釣灯籠のやうなシャンデリ アを二個吊しました。四方の風鐸形も電灯です。と述べている。能 楽堂改良会ではガスか電灯かで議論していた際に、「ある程度まで なら瓦斯でもできる」という考えを示していたが、タングステンフ イラメント電球が開発されたことにより、大正期には電灯が瓦斯灯 を駆逐して行くことになり、ここでは電灯が使用されている。また、 二階に栈敷席を設けた為に天井が高くなってしまい、その締りのな さを補う意味もあり、シャンデリアを二つ吊るしたとある。能楽堂 改良会で採光案の際に話し合われていた「下手に隠すより上手に露 出し」と論じた後藤の提案を反映しているとも言える。また、シャ ンデリアは鈞登篭のような形をした和風なものとしているが、この 点についても、能楽堂改良会で山崎が、「日本の古来の燈明は短棨、 行灯、燭台等皆下八据えているもので、吊って上から光を取るもの がないから、上から光を取るといふ事はどう工夫しても能舞台など
には調和するものが出来ません。」と述べたことに対し、後藤が「上 から吊る燈明がないとの御話ですが、釣燈篭は上から吊るじゃあり ませんか」と反論されたが、まさにこの反論通りのデザインを採用 したことになる。

\section{（5）能舞台}

能舞台について山崎は「舞台で、これは新築したものではありま せん。昔青山下野守とかいふ大名の舞台であつたのが維新後梅若家 の所有に帰したもので、大変いい檜を使った結構な舞台です。今度 の改築で位置も変はり、床下は音調上すつかり特殊の工事と施した 外、外形上には屋根の瓦莫を檜皮亘に改め、破風を取り換へ、橋掛 も約一間延長しました。と述べていることから、この能舞台は梅若 実が 1872 (明治 5）年に自宅に建てた能舞台を移築したものである ことがわかる注 22 )。屋根の莫き替えと橋掛りを延長しているが、基 本的な形状はそのまま保持したと言えるだろう。これに関しても、 能舞台研究会での能舞台は原型を保持という基本的な考え方が踏襲 された。

\section{（7）食堂}

能楽堂の食堂は、表通りに面した二階に設けてあり、椅子式とし ている。調理場はその下の一階に設けてある。調理場から食堂へ八 ンドリフト設けて料理を上下させる仕掛けを施した。この点につい ては、敷地一杯に配置された 1 階の平面図から見て、食堂を 1 階に 設けることが難しかったことが伺える。また、蝔房は、給排水等の 都合により 1 階に設け、見所からなるべく離れていた方が良いため、 食堂を 2 階に設けたという見方もできよう。そして、それを可能に したのが、ハンドリフトの設備であった。つまり、能楽堂改良会注 23$)$ の議論で後藤が述べた「食堂を完全にすることは同感です。同時に 弁当箱を持ち込む事は完全な能楽堂と云ふ上からは不賛成です。食 堂は観客席とはなして騒ぎが席の方へ聞こえないやうに設備するの は無論のことです」という主張と合致している。

\section{(8) その他}

見所で 2 階席の張り出しを支持していたのは鉄柱である。この点 について山崎は「鐵の支柱は漆で臘色塗にし、一寸したキャピタル は箔を置きました。これは効果がありました。と述べている。見所 に鉄の支柱を使い、目立た妨り臘色塗としているのは、明治期 の囲繞式能楽堂では常套の手法で、能楽社でも使われており注 24)、 移築後の九段能楽堂でも引き続き使われていた。この辺りも山崎は 参考にした可能性が高い。

また、山崎は「天井には空気抜を三ヶ所設け、小屋裏に電気扇を 四台据えてヴェンチレーションを謀って置きました。その空気抜の 彫物は写真には見えてみませんが、青海波に松として、神能の筆頭 たる高砂のつもりに描きました。と述べたように、見所の衛生上の 配慮として、換気設備を設けていたことがわかる。この点に関して は、山崎が能楽堂改良会注25)で、「それから通風のことはそれ程も 問題ではありませんが、夏季に涼を容れる為めには大きな電気扇を 用みる位の事は、今は寄席だつてやつてみるのですから、能楽堂に は無論あつて然るべきでせう。」と発言していたが、その通りに機械 換気が採用されていたことになる。 


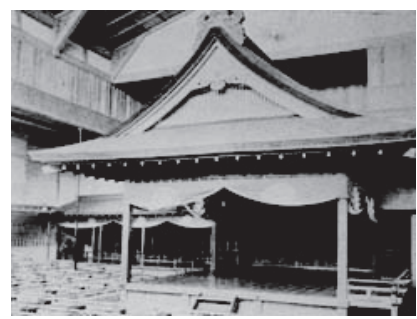

図 5 梅若家能楽堂能舞台 (『建築 雑誌』34 巻 398 号, 1920 年 1 月)

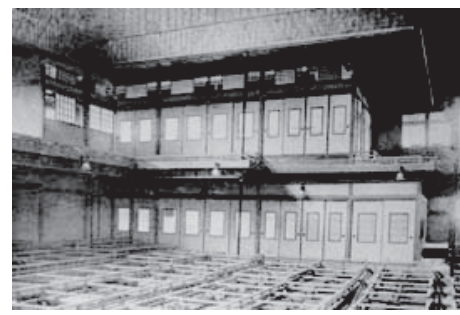

図 6 梅若家能楽堂見所 (『建築雑誌』 34 巻 398 号, 1920 年 1 月)

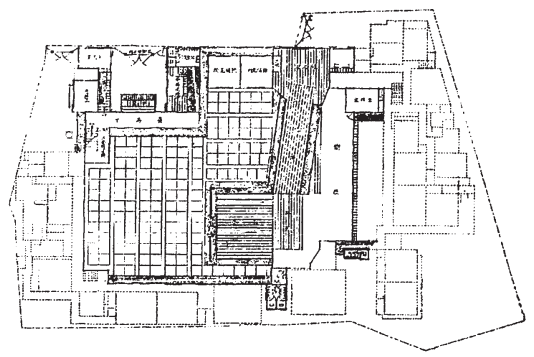

図 7 梅若家能楽堂平面図 (『建築世界』13 巻 11 号, 1919 年 11 月)

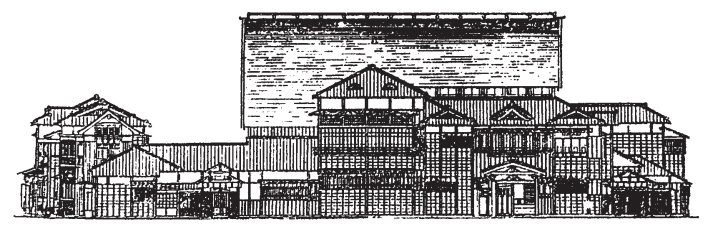

図 8 梅若家能楽堂立面図（『建築世界』13 巻 11 号, 1919 年 11 月）

\section{4.まとめ}

山崎静太郎は、「能舞台研究会」と「能楽堂改良会」の中心メンバ 一であったが、今回の細川家能楽堂と梅若家能楽堂の設計内容の検 証により、二つの会での議論が確実に反映されていたことが分かっ た。特に、後藤慶二との論議が設計に大きな影響を及ぼしており、 一連の議論が入れ子式能楽堂設計の原動力となったと言っても過言 ではないだろう。具体的には、能舞台を覆う見所の大空間では、構 造的難点を伴うが、能舞台の屋根が見所から見えることが重視され、 それは、能舞台研究会での能舞台の伝統様式を尊重する考え方を反 映するものでもあった。しかし、山崎は能舞台の設計において、能 舞台以外に他の建築物の歴史を交えており、能舞台の進化について も論じていた注 2 6) 山崎の創作の一端として捉えることも出来るだ ろう。また、梅若能楽堂に食堂が設けられたことは、改良劇場に追 い付こうとした当時の能楽堂改良の片鱗を示寸ものとして注目され る。以上のように、山崎静太郎は能楽堂改良議論と能楽堂設計の双 方に係わった唯一の建築家であったが、今回の検証により、能楽堂 改良論が入れ子式能楽堂の設計に深い影響を与えた点を山崎静太郎 の設計した二つの能楽堂の設計経緯を通して確認することができた。

\section{謝辞}

本論の検証においては、永青文庫から細川家能楽堂に関する貴重 な資料の提供を頂きました。ここに記して感謝の意を表します。
注 1 ）池内如翠「久米博士に呈す」、『能楽』第 13 卷 5 号 1915 （大正 4 ）年 5 月 $\mathrm{p} 31$ 、雑誌『能楽』の刊行主の池内信嘉は、「我輩の能楽改良論」を 1914 （大正 3）年 11 月に東京音楽学校で論じ、能楽改良論を紹介した。

注 2 ）山崎静太郎「新能楽堂三つ」建築雑誌 34 卷, 第 398 号, pp113-117, 1920 年 1 月

注 3 ）山崎静太郎「細川侯爵家新築能楽堂の概様」(上) ・(下)『能楽』第 15 卷、 10 号・ 12 号、1918（大正 7) 年 10 月・ 12 月)

注 4 ）「趨町区富士見町戴丁目五番地ノ戴 貸家家屋台帳 家政所」1931（昭 和 6) 年 11 月、永青文庫所蔵

注 5 ) 前掲注 4 所収タイトル「細川家富士見町邸実測平面図縮尺三百分の一」 昭和六年九月実測、原本不鮮明のため敷地境界線と建物の輪郭をトレ ースし、実測値は割愛した。

注 6 ）前掲注 4 所収タイトルなし、原本不鮮明のため建物の輪郭や室名をそ のままトレースした。前掲注 3 では、公衆入口が一般入り口、正玄関 が主玄関と表記される。

注 7 )「細川侯爵家新築能楽堂の概要（上）」、能楽』 15 巻 10 号、能楽館、 $1932 （ 大$ 正 7) 年 10 月、pp72-75

注 8 ） 前掲注 7 掲載

注 9 ) 『能楽』第 9 巻 8 号、能楽館、1911（明治 44）年 8 月、下足受渡改良 案第 1 案から第 4 案を提示して式台の数と形状を検討している。

注 10 ）『能楽』第 9 巻 1 号、能楽館, 1911（明治 44）年 1月、「舞台見所の 関係改良論」

注 11 ） 奥富利幸「明治末期から昭和初期の邸宅における能楽空間の変容— 見所の拡大と白州の室内化」『日本建築学会計画系論文集』第 73 巻 627 号、pp 1083-1088、2008 年 5 月、浅野侯爵家滝野川別邸能舞台 は囲繞式能楽堂で、能舞台周囲の白州上部にトラスを用いた天空を 架けて能舞台の屋根が見所から眺められたと考えられる。

注 12 ）宝生会能楽堂 1913 （大正 2）年竣工、舞台設計：大島盈株、工事監 督: 遠藤於蒬、入れ子式能楽堂であるが能舞台の屋根の一部が天井 に隠れており、不完全な入れ子となっている。

注 13 ）『能楽』第 9 巻 2 号、能楽館、1911（明治 44）年 2 月、「見所間取及 び席割の改良案」

注 14 ）『能楽』第 9 巻 4 号、能楽館、1911（明治 44）年 4 月、「能舞台の採 光案」

注１５）山崎が「上屋の妻から高く明かりを取る事にした。と述べた明かり を採光と判断した理由は、上屋となる能楽堂の妻から明かりを取る という表現から、採光と解釈した。図1の光の射し方を見ると照明 より強くて均一で、光源面積が広い光に見える。つまり、こうした 光の照らし方は照明では難しく、採光と判断した。

注 16 ）『能楽』第 9 巻 5 号、能楽館、1911（明治 44）年 5 月、「楽屋の設備」

注 17 ) 『能楽』第 8 巻 11 号、能楽館、1910（明治 43）年 11 月、能舞台の 屋根形状の変遷を議論する。

注 18 ）『時事新報』1919（大正 8）年 9 月 11 日、「梅若能楽堂改築祝 浅草 南元町の梅若舞台は今回改築落成したるを以て、二十一日正午十二 時より其祝能を催す。」

注 19 ） 白洲正子『梅若実聞書』1945（昭和 20）年 4 月 25 日、p12

注 20 ）『能楽』第 9 巻 1 号、能楽館、1911（明治 44）年 1 月、「舞台見所の 関係改良案」

注 21 ）『能楽』第 9 巻 2 号、能楽館、1911（明治 44）年 2 月、「見所間取り 及び席割の改良案」

注 22 ）梅若実「舞台を得るまで」『能楽』能楽館、1903（明治 36）年、こ の能舞台は青山下野守の屋敷にあったもので、一橋家の平岡熙一之 いう人が梅若家の門下でこの能舞台を梅若実に紹介したものである。

注 23 ）『能楽』第 9 巻 7 号、能楽館、1911（明治 44）年 7 月, 「食堂案」

注 24 ）奥冨利幸「明治初期における能楽堂誕生の経緯：青山御所能舞台、 能楽社の建設を通して」日本建築学会計画系論文集、第 565 号)、 pp 337-342、2003 年 3 月、日本建築学会

注 25 )『能楽』第 9 巻 11 号、能楽館、1911（明治 44）年 11 月、結会記事 注 26 ）山崎静太郎「能舞臺新古鑑別の事」、建築䧴誌』 24 巻 285 号、 pp469-474、1910 年 9 月 